\title{
The distribution and diel movements of Brünnich's Guillemot Uria lomvia in ice covered waters in the Barents Sea, February/March 1987
}

\author{
VIDAR BAKKEN
}

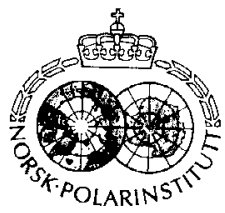

Bakken, V. 1990: The distribution and diel movements of Brünnich's Guillemot Uria lomvia in ice covered waters in the Barents Sea, February/March 1987. Polar Research 8, 55-59.

The distribution of Brünnich's Guillemot in ice covered waters and near the marginal ice zone in the southern part of the Barents Sca was mapped from ship and helicopter in February/March 1987. High densities of Brünnich's Guillemot (up to 1,300 ind. $/ \mathrm{km}^{2}$ ) were found in ice leads. The density of birds was especially high over shallow banks where the sea depth was $40-80 \mathrm{~m}$.

A diel movement was also recorded. In the evening the birds left the leads and flew south. Next morning they returned to fecd in the open leads. How far they migrated is uncertain, but possibly they ficw down to the open sea or to leads close to the marginal ice zone. The migration may have been a means of avoiding to become trapped if leads closed after dark.

Vidar Bakken, Norsk Polarinstitutt, P.O. Box 158, N-1330 Oslo Lufthavn, Norway; October 1989 (revised February 1990).

The Brünnich's Guillemot is one of the most numerous seabird species in the Barents Sea. Breeding colonies are found on the Norwegian coast (only in small numbers), in the Svalbard area and in the Soviet territories (Frans Josef Land, Novaja Zemlja and the Murman coast) (Fig. 1) (Norderhaug et al. 1977; Golovkin 1984; Mehlum \& Fjeld 1987). More than 600,000 pairs breed in the Svalbard area (Mehlum \& Fjeld 1987; Bakken \& Mehlum 1988; Knutsen et al. 1988; Kempf \& Sittler 1988), while according to Golovkin (1984), the total breeding population in the Soviet territories is more than one million pairs.

Ringing recoveries have shown that Brünnich's Guillemots breeding on the west coast of Spitsbergen and on the Murman coast migrate towards waters southwest of Greenland in winter (Norderhaug et al. 1977; Kampp 1988). Despite that more than 50,000 Brünnich's Guillemots have been ringed on Novaja Zemlja (Uspenski 1958), only a few have been recovered from Greenland (Salomonsen 1967, 1971; Kampp 1988), and many probably stay south of the ice covered areas in the eastern part of the Barents Sea during the winter (Uspenski 1958). Counts of seabirds in the southern Barents Sea in 1986-1988 have shown that the Brünnich's Guillemot was a common species south of the ice covered waters in winter (Anker-Nilssen et al. 1988).
In early spring, high densities of Brünnich's Guillemot have been recorded in leads near the breeding colonies at Svalbard (Norsk Polarinstitutt unpublished), but if they also exploit the ice covered waters in winter is unknown. In the Bering Sea high densities of guillemots have been observed in March, both in leads and near the marginal ice zone (Irving et al. 1970).

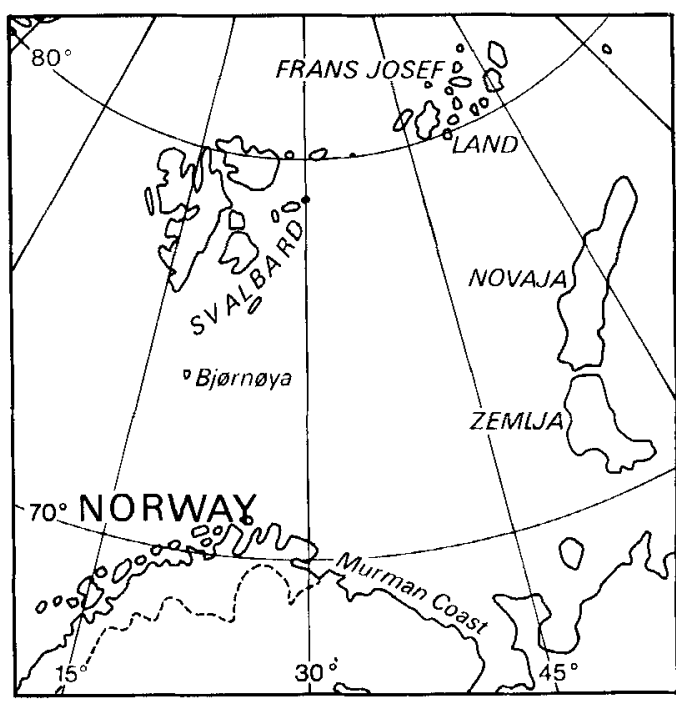

Fig. 1. Map of the Barents Sea. 
In this paper I present results of counts of Brünnich's Guillemots in the ice covered waters in the Barents Sea in February/March 1987, during which period a diurnal migration was recorded. The possible causes for this migration are discussed.

\section{The ice conditions in the Barents Sea}

Most of the ice in the Barents Sea is formed locally (Vinje 1985). During the winter, it gradually extends southwards, and surrounds the breeding colonies in the northern part of the Barents Sea (Svalbard, Frans Josef Land and Novaja Zemlja). However, the extent of the ice cover varies greatly from year to year (Fig. 2).

The ice drift is influenced mostly by the wind, and the occurrence and distribution of open leads are highly dependent on wind speed and direction (Vinje 1985). Southerly winds compact the ice and close the leads, while northerly winds have the opposite effect. There are no areas within the ice covered waters which are permanently open during the winter period.

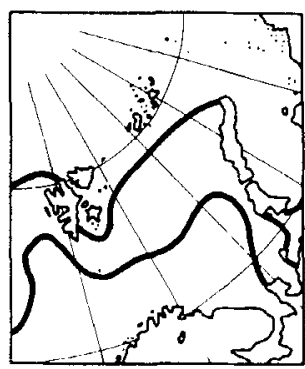

DECEMBER

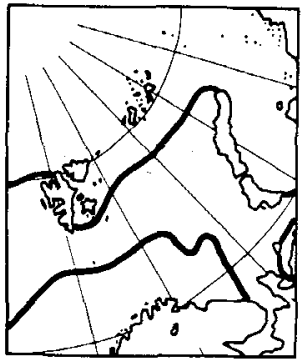

FEBRUARY

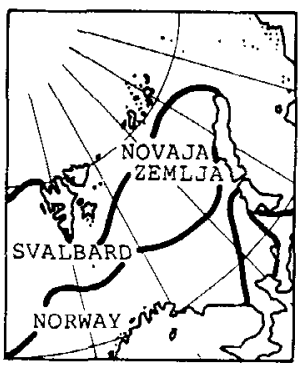

JANUARY

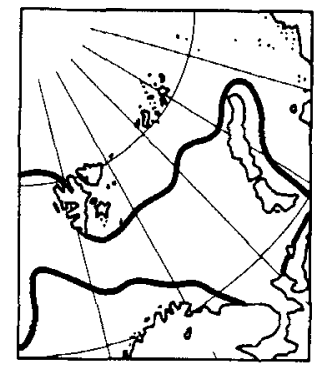

MARCH
Fig. 2. Maximum and minimum extension of sea ice in the Barents Sea in December-March based on long-term Russian observations (after USSR Ministry of Defence 1980).

\section{Methods}

Counts were made from K.V. 'Nordkapp', a Norwegian coastguard vessel, and from a helicopter which was based on the ship. Ship-based counts were made in daytime from one side of the bridge ( $16 \mathrm{~m}$ a.s.l) by a method described by Tasker et al. (1984). When the ship was anchored, counts of flying guillemots were made in the morning and evening from an observation platform (26 $\mathrm{m}$ a.s.l.).

Counts from the helicopter were made at a speed of c. 90 knots and at a height of c. 200 feet. Two observers, one on each side, recorded birds seen in a $200 \mathrm{~m}$ wide $(100 \mathrm{~m}$ on each side of the helicopter) transect.
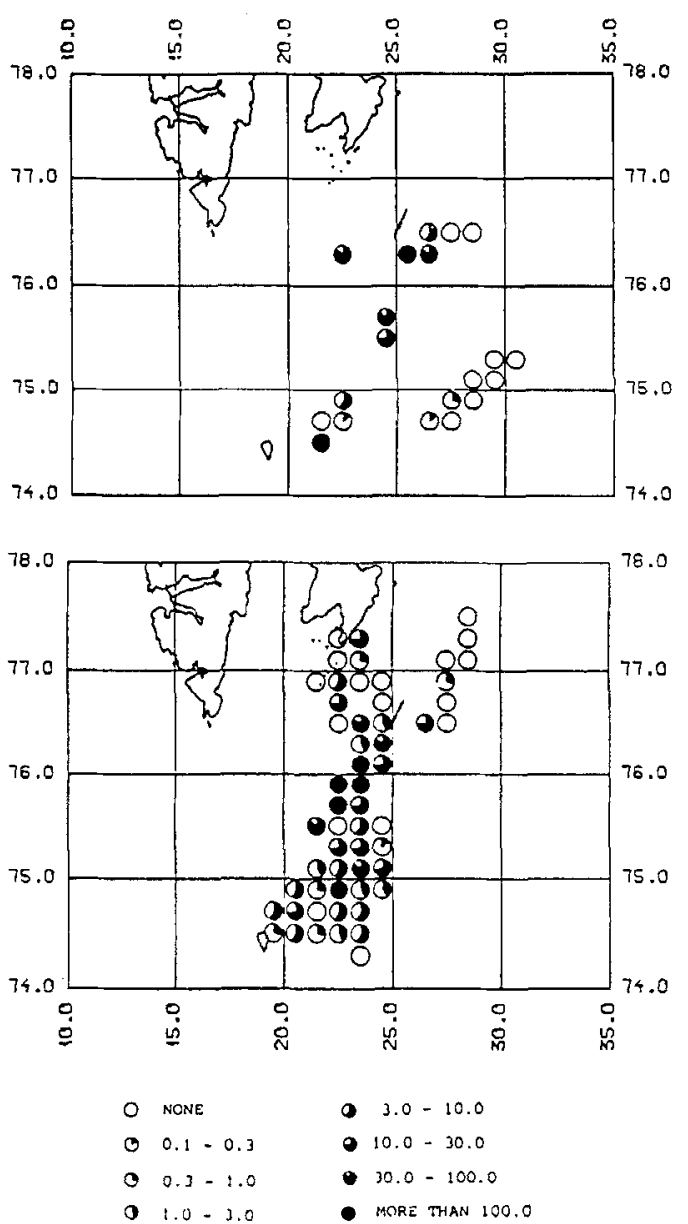

Fig. 3. Densities (number of birds per $\mathrm{km}^{2}$ ) of Brünnich's Guillemots observed from the boat (top) and helicopter (bottom) in the ice covered waters and close to the marginal ice zone in the Barents Sea, February/March 1987. 
The areas covered by the ship and helicopter surveys are shown in Fig. 3. The data presented were collected from 27 February to 8 March.

\section{Results}

The distribution of Brünnich's Guillemot was patchy in the ice covered waters, with lower densities of birds in the eastern part of the study area (Fig. 3). The highest densities (up to 1,300 birds/ $\mathrm{km}^{2}$ ) were seen in leads south and west of Hopen (Fig. 4). In this area there are shallow banks with sea depths from 40 to $80 \mathrm{~m}$, as compared to depths of c. 150 to $300 \mathrm{~m}$ in the eastern sector. The distance from this area to the southerly marginal ice zone was about $150 \mathrm{~km}$. Open leads were found throughout the area investigated.

In the western part of the study area, between Hopen and Bjørnøya (Fig. 4), we noted a distinct migration of Brünnich's Guillemots every morning and evening. Just before dusk, the guillemots left the leads and flew south. In the morning they returned, and stayed in the leads for 7-10 hours. At night, there were almost no guillemots left in the area. The main northerly migration took place between 0700 and $1000 \mathrm{hrs}$. and the southerly migration between 1400 and $1700 \mathrm{hrs}$. (GMT). Numbers flying past one side of the ship were counted three times (twice in the morning and once in the evening) (Table 1). The total number of birds migrating was much higher than shown in Table 1.

During the survey, which lasted 14 days, the ice distribution changed greatly, with a general eastward shift of the western edge of the marginal ice zone (Fig. 4). This change also influenced the distance from the main area, where the guillemots were observed southwest of Hopen, to the marginal ice zone. In the last part of the survey, the distance to the western marginal ice zone was about the same as to the southern marginal ice zone (Fig. 4). One night during this period the

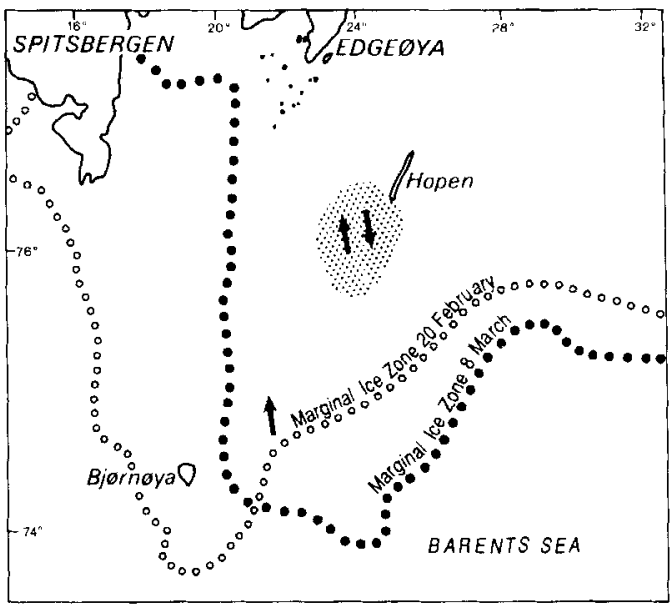

Fig. 4. The study area with the positions of the marginal ice zone at the start and at the end of the survey. The arrows indicate where and in which dircetion a diurnal migration of Brünnich's Guillemots was registered. The arrows pointing north are morning migrations and the arrow pointing south is an evening migration. The dotted area indicates where the highest densities of Brünnich's Guillemots in leads were observed.

crew on the bridge observed 'large flocks' of Brünnich's Guillemot in the ship's search-light in big leads close to the western marginal ice zone. Because no migration observations were made the previous evening or the next morning, $I$ do not know if there also was a shift in the migration direction.

\section{Discussion}

The high densities (up to $1,300 / \mathrm{km}^{2}$ ) of Brünnich's Guillemots show that the southern parts of the ice covered waters of the Barents Sea were important for this species in February/March. When passing the breeding colonies on Hopen and Bjørnøya in the helicopter, no birds were observed on the breeding ledges which were

Table 1. Three counts of migrating Brünnich's Guillemots observed on one side of the ship in the Barents Sea, February/March 1987.

\begin{tabular}{lllcl}
\hline Date & Time (GMT) & Position & Number of migrating birds & Direction \\
\hline 27 Feb. & $0740-1140$ & $74^{\circ} 40^{\prime} \mathrm{N} 21^{\circ} 56^{\prime} \mathrm{E}$ & 6,440 & North/northwest \\
$04 \mathrm{Mar}$. & $1400-1600$ & $76^{\circ} 20^{\prime} \mathrm{N} 25^{\circ} 00^{\prime} \mathrm{E}$ & 7,903 & South/southeast \\
$06 \mathrm{Mar}$. & $0700-1000$ & $76^{\circ} 05^{\prime} \mathrm{N} 23^{\circ} 40^{\prime} \mathrm{E}$ & 10,564 & North/northwest \\
\hline
\end{tabular}


covered with snow. Hence, the occurrence of the guillemots in the ice covered waters was probably not connected to the use of the colony prior to the breeding season.

In the Barents Sea, the formation of leads is almost totally dependent on the wind (Vinje 1985). Meteorological data from the southern part of the Barents Sea during a 30 year period show that the predominant wind-direction in winter is from the north-east (Steffensen 1982). Leads form on the leeward side of the island (T. Vinje pers. comm.); hence, the probability of finding open leads southwest of Hopen in winter is high. Here tides probably also influence their formation, particularly in shallow areas where currents may be faster (T. Vinje pers. comm.). The area may thus be of great importance for Brünnich's Guillemots when the sea is otherwise covered by ice. Leads may similarly form south of the islands further north (Spitsbergen and Edgeøya), but if the birds have to spend the night in open water the distance to the marginal ice zone is much longer.

We have few data showing where the birds spent the night, but two observations indicate that the birds migrated to the marginal ice zone or to big open leads close to it. Birds observed on a northerly morning migration near Bjørnøya were only a few $\mathrm{km}$ from the marginal ice zone (Fig. 4). The night observation of 'large flocks' in open water near the western marginal ice zone also suggests a daily migration to this area.

The evening migration from the ice covered waters could be caused by the danger of being trapped in the ice at night when leads may close. Because of small wingloading (Rüppel 1975), guillemots need considerable room to take flight from the water. During other surveys in ice covered waters in the Barents Sea, I have observed Brünnich's Guillemots trapped in small leads and being unable to take off. In strong winds Brünnich's Guillemots may manage to get alight from an icefloe, but in most cases they fail (personal observation).

This diel movement was only observed over a four day period when the ship stayed south and west of Hopen, and I do not know if this migration is the regular pattern throughout the winter. If the birds depend on light for feeding in the ice covered waters, it will probably be impossible to exploit these areas in December and January because of the dark period. At Hopen the sun is below the horizon from 2 November to 9 Febru- ary. A similar diel movement for Brünnich's Guillemots in ice covered waters has not previously been recorded, but there are earlier observations of high densities of guillemots near the marginal ice zone and in leads elsewhere (Irving et al. 1970; Divoky 1979; Bradstreet 1980, 1982).

The profit of feeding in the leads must have been high in relation to a daily return flight of up to $300 \mathrm{~km}$ (assuming they flew from the marginal ice zone). During our survey, the feeding conditions in the leads were good. Stomach analyses of 30 Brünnich's Guillemots shot in the leads showed that the staple food was the amphipod Parathemisto libellula and the Polar Cod Boreogadus saida (F. Mehlum \& G. Gabrielsen pers. comm.). The mean body weight of the birds was 1,066 grams $(\mathrm{SD}=113, \mathbf{n}=30)$, which is among the highest recorded during the year in the Svalbard area (F. Mehlum \& G. Gabrielsen pers. comm.; personal observation). Stomachs of birds shot in open water near the marginal ice zone in the same time period contained mostly Polar Cod and amphipods, but the samples were well digested (Erikstad 1990), suggesting that the birds had caught the food earlier (and possibly elsewhere).

Gulliksen \& Lønne (1989) have shown that the sympagic fauna in this area is rich in Polar Cod and amphipods, and these resources are perhaps easier to catch for the birds than prey in the open sea at this time of year. This may explain why the guillemots migrated into the ice covered waters each day.

Acknowledgements. - Thanks are due to Geir Wing Gabrielsen and Egil Soglo who helped counting birds. I am grateful to Geir Wing Gabrielsen and Fridtjof Mehlum for letting me use their unpublished data and for their comments on the manuscript. 1 am also grateful to Kjell Einar Erikstad, Rob Barrett and an anonymous referee for valuable comments. Rob Barrett also improved the English. Many thanks to the crew and helicopter pilots on the coastguard vessel $K / \mathrm{V}$ 'Nordkapp' for their help and hospitality.

This study was financed by the Norwegian Department of Oil and Energy as a part of an environmental impact analysis in connection with planned oil/gas drilling in the southern part of the Barents Sea.

\section{References}

Anker-Nilssen, T., Bakken, V. \& Strann, K-B, 1988: Konsekvensanalyse olje/sjøfugl ved petroleumsvirksomhet i Barentshavet $\mathrm{s} \phi \mathrm{r}$ for $74^{\circ} 30^{\prime} \mathrm{N}$. Viltrapport 46.98 pp. + Appendix. 
Bakken, V. \& Mchlum, F. 1988: AKUP-Sluttrapport. Sjøfuglundersøkelser nord for $\mathrm{N} 74^{\circ} / \mathrm{Bj} ø$ rnøya. Norsk Polarinst. Rapportserie 44.127 pp.+Appendix.

Bradstreet, M. S. W. 1980: Thick-billed murres and black guillemots in the Barrow Strait, N.W.T., during spring: diets and food availability along ice edges. Can. J. Zool. 58,21202140.

Bradstreet, M. S. W. 1982: Occurrence, Habitat Use, and Behaviour of Seabirds, marine Mammals, and Arctic Cod at the Pond Inlet Ice Edge. Arctic 35, 28-40.

Divoky, G. J. 1979: Sea ice as a factor in seabird distribution and ecology in the Beaufort, Chukchi, and Bering Seas Pp. $7-19$ in Bartonek, J. C. \& Nettleship, D. N. (eds.) Conservation of Marine Birds of northern North America. Fish Wildl. Serv. Res. Rep. 11.

Erikstad, K. E. 1990: Winter diets of 4 seabird specics in the Barents Sea after a crash in the capelin stock. Polar Biol. (in press).

Golovkin, A. N. 1984: Seabirds Nesting in the USSR: The Status and Protection of Populations. Pp. 473-486 in Croxall, J. P., Evans, P. G. H. \& Schreiber, R. W. (eds.): Status and Conservation of the World's Seabirds. ICBP Techn. Publ. 2.

Gulliksen, B. \& Lønne, O. J. 1989: Distribution, abundance, and ecological importance of marine sympagic fauna in the Arctic. Rapp. P.-v. Reun. Cons. int. Explor. mer 188, 133138.

Irving, L., McRoy, C. P. \& Burns, J. J. 1970: Birds observed during a cruise in the ice-covered Bering Sea in March 1968. Condor 72, 110-112.

Kampp, K. 1988: Migration and winter ranges of Brünnich's Guillemots Uria lomvia brceding or occurring in Greenland. Dansk Orn. Tidsskr. 82, 117-130.

Kempf, C. \& Sittler, B. 1988: Census of breeding seabirds on the northwest coast of Svalbard 1973 and 1978. Polar Research 6, 195-203.

Knutsen, L. Ø., Fjeld, P. E. \& Olsson, O. 1988: Sjøfuglundersøkciser på $\emptyset$ st-Spitsbergen, Svalbard, med konsekvensvurdering av aktivitet på Haketangen. Pp. 79-114 in Prestrud, P. \& Øritsland, N. A. (eds.): Miljøundersøkelser i tilknytning til petroleumsvirksomhet på Svalbard 1987. Norsk Polarinst. Rapportserie 41.

Mehlum, F. \& Fjeld, P. E. 1987: Catalogue of scabird colonies in Svalbard. Norsk Polarinst. Rapportserie 35. 222 pp.

Norderhaug, M., Brun, E. \& Møllen, G. U. 1977: Barentshavets sjøfuglressurser. Norsk Polarinst. Meddelelser 104. 119 pp.

Rüppel, G. 1975: Fugle - Fardigheter, Flukt og Fart. Lademann. $184 \mathrm{pp}$.

Salomonsen, F. 1967: Fuglene på Gronland. Rhodos. 34] pp.

Salomonsen, F. 1971: Recoveries in Greenland of birds ringed abroad. Medd. om Gronland 191. $52 \mathrm{pp}$

Steffensen, E. 1982: The Climate at Norwegian Arctic Stations. Klima 5. 44 pp.

Tasker, M. L., Hope Jones, P., Dixon, T. J. \& Blake, B. F. 1984: Counting seabirds at sea from ships: a review of methods employed and a suggestion for a standardized approach. Auk 101, 567-577.

Uspenski, S. M. 1958: The bird bazaars of Novaya Zemlja. Canadian Wildl. Serv. Translations of Russian Game Reports 4. Ottawa. $159 \mathrm{pp}$.

USSR Ministry of Defence (Gorskov, S. G. \& Faleev, V. I. (eds.)) 1980: Atlas of the Oceans. The Arctic Ocean.

Vinje, T. 1985: Drift, composition, morphologhy, and distribution of the sea ice ficlds in the Barents Sea. Norsk Polarinst. Skrifter 179 C. $26 \mathrm{pp}$. 
